\title{
An improvement of the Ramanujan formula for approximation of the Euler gamma function
}

\section{CRISTINEL MORTICI}

\section{ABSTRACT.}

The aim of this paper is to improve a double inequality due to Ramanujan for approximation of the Euler gamma function.

DEPARTMENT OF MATHEMATICS

VALAHIA UNIVERSITY OF TÂRGOVIŞTE

UNIRII 18, 130082 TÂRGOVIŞTE, ROMANIA

E-mail address: cmortici@valahia.ro 